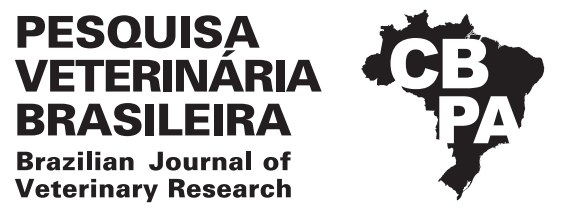

Pesq. Vet. Bras. 39(1):61-65, janeiro 2019 DOI: 10.1590/1678-5150-PVB-5735

Original Article

ISSN 0100-736X (Print)

ISSN 1678-5150 (Online)

\title{
Evaluation of tear production in juvenile opossum using three different methods ${ }^{1}$
}

\author{
Arianne P. Oria ${ }^{2 *}$ (D), Ana C. Raposo², Nayone L.L.C. Araujo², João V. Romano², \\ Emanoel F. Martins-Filho ${ }^{2}$, Deusdete Gomes Junior ${ }^{3}$ and Paula D. Galera ${ }^{4}$
}

\begin{abstract}
Oria A.P., Raposo A.C., Araujo N.L.L.C., Romano J.V., Martins Filho E.F., Gomes Junior D. \& Galera P.D. 2019. Evaluation of tear production in juvenile opossum using three different methods. Pesquisa Veterinária Brasileira 39(1):61-65. Departamento de Anatomia, Patologia e Clínicas Veterinárias, Universidade Federal da Bahia, Avenida Adhemar de Barros 500, Salvador, BA 41710-110, Brazil. E-mail: arianneoria@ufba.br

The establishment of parameters for tear production in different species is important for better understanding eye's health and is one of the components of the ophthalmic semiological technique. Particularities derived from the anatomophysiology of non-domestic species induce the search for more reliable methodologies. The aim was to evaluate and compare tear production of white-eared opossum (Didelphis albiventris) and Brazilian common opossum (Didelphis aurita) by three different methods. Fifteen individuals of each species, juveniles, healthy, of both sexes, with 60 to 90 days of life, were physically restrained. Phenol red thread test (PRTT), endodontic absorbent paper point tear test (EAPPTT) and modified -Schirmer tear test (mSTT) were performed. PRTT was the most difficult to perform because of the wire malleability, while EAPPTT was more feasible for both species. The median \pm semi-quartile range for PRTT were $19.79 \pm 2.61 \mathrm{~mm} / 15$ "and $5.22 \pm 2.92 \mathrm{~mm} / 15$ ", for EAPPTT were $16.25 \pm 1.82 \mathrm{~mm} / \mathrm{min}$ and $10.9 \pm 3.04 \mathrm{~mm} / \mathrm{min}$, and for STTm were $0 \pm 1.63 \mathrm{~mm} / \mathrm{min}$ and $0 \pm 1.63 \mathrm{~mm} / \mathrm{min}$ for white-eared opossum and Brazilian common opossum respectively. There was no difference between the right and left eye neither sex. A significant difference was obtained for the same test to different species. No significant correlation was found between the tests for both species. The description of tear production parameters for juvenile white-eared opossum and Brazilian common opossum may be used as a tool, which will allow the early diagnosis of ocular diseases.
\end{abstract}

INDEX TERMS: Tear production, juvenile opossum, marsupials, phenol red thread test, endodontic absorbent paper point tear test, modified-Schirmer tear test, wild animals.

\footnotetext{
RESUMO.- [Avaliação da produção lacrimal em gambás filhotes por três diferentes métodos.] 0 estabelecimento do parâmetro de produção lacrimal nas diferentes espécies é importante para o entendimento da saúde do olho e é um dos componentes da semiotécnica oftálmica. Particularidades derivadas da anatomofisiologia das espécies não domésticas

${ }^{1}$ Received on June 27, 2018.

Accepted for publication on July 9, 2018.

${ }^{2}$ Escola de Medicina Veterinária e Zootecnia, Universidade Federal da Bahia (UFBA), Av. Adhemar de Barros 500, Ondina, Salvador, BA 40170-110, Brazil. *Corresponding author: arianneoria@ufba.br

${ }^{3}$ Universidade Federal do Oeste da Bahia, Avenida 23 de agosto, Barra, BA 47100-000, Brazil.

${ }^{4}$ Faculdade de Agronomia e Medicina Veterinária (FAV), Universidade de Brasília (UnB), ICC Sul Campos Universitário Darci Ribeiro, Brasília, DF 70297-400, Brazil.
}

induzem a busca de metodologias que sejam mais fidedignas aos parâmetros. Objetivou-se com este estudo avaliar e comparar a produção lacrimal de gambás-de-orelha-branca (Didelphis albiventris) e gambás-de-orelha-preta (Didelphis aurita) por três diferentes métodos. Quinze indivíduos de cada espécie, juvenis, hígidos, de ambos os sexos, com 60 a 90 dias de vida, foram contidos fisicamente para realização do teste lacrimal do vermelho de fenol (TLVF), da ponta de papel absorvente estéril e do teste lacrimal de Schirmer modificado (TLSm). 0 TLVF foi o mais difícil de ser executado devido à maleabilidade do fio, enquanto a TEPA se mostrou mais exequível para ambas as espécies. A mediana \pm intervalo semi-interquartil para 0 TLVF foi de $19,79 \pm 2,61 \mathrm{~mm} / 15$ " e $5,22 \pm 2,92 \mathrm{~mm} / 15$ ", para a TEPA foram de $16,25 \pm 1,82 \mathrm{~mm} / \mathrm{min}$ e $10,93 \pm 3,04 \mathrm{~mm} / \mathrm{min}$, e para o TLSm foram de $0 \pm 1,63 \mathrm{~mm} / \mathrm{min}$ e $0 \pm 1,63 \mathrm{~mm} / \mathrm{min}$, para gambás-de-orelha-branca e gambás-de-orelha-preta, 
respectivamente. Não houve diferença entre o olho direito e esquerdo e nem quanto ao sexo. Obteve-se diferença significativa para um mesmo teste entre as espécies. Não foi encontrada correlação significativa entre os testes para ambas as espécies. A quantificação da porção aquosa da lágrima poderá auxiliar no diagnóstico precoce de doenças oculares nas espécies estudadas.

TERMOS DE INDEXAÇÃO: Produção lacrimal, gambás filhotes, teste lacrimal do vermelho de fenol, tira endodôntica de papel absorvente, teste lacrimal de Schirmer modificado, sariguê, marsupiais, animais silvestres.

\section{INTRODUCTION}

The opossums, genus Didelphis, are marsupials with oval ears and prehensile tail, widely distributed in South America, which have nocturnal, omnivorous and opportunistic habits, and record of occurrence in a peri-urban environment (Cáceres \& Monteiro-Filho 1998, Cáceres 2000, Astua de Moraes et al. 2015, Costa et al. 2015).

These animals were described as an experimental model for eye studies due to their immature condition at birth (Mcmenamin \& Krause 1993) and it often is referred to rehabilitation centers due to the death of the progenitor (Cáceres 2000). Ulcerative lesions and bacterial conjunctivitis are common in opossum; however, there are few descriptions on ophthalmic parameters of marsupials (Mcmenamin \& Krause 1993, Cáceres 2000).

Quantitative measurement of tear film is one of the stages of the ophthalmic semiotechnique, and the composition and adequate volume of tears are responsible for the ocular surface homeostasis (Ghaffari et al. 2012, Trbolova \& Ghaffari 2012). Schirmer tear test (STT) is considered the gold standard for the quantitative evaluation of this fluid, with reports for humans, domestic and wild animals (Beech et al. 2003, Trost et al. 2007, Ghaffari et al. 2012, Trbolova \& Ghaffari 2012). However, modifications were suggested to species with palpebral fissure length smaller than the width of the strip (5.0mm), adapting it to $2.5 \mathrm{~mm}$ (mSTT) (Conceição et al. 2011, Lange et al. 2012, Silva et al. 2013, Somma et al. 2015).

As alternative to animals with small eyes or decreased basal and reflex tear production, the phenol red tear test (PRTT) was used (Araujo et al. 2017). It is a cotton thread impregnated with phenol red dye, sensitized in contact with the normal $\mathrm{pH}$ of the skin. Its use was described in birds, which had small eyelid and required rapid physical restraint (Hida et al. 2005, Holt et al. 2006, Trost et al. 2007, Blackwood et al. 2010, Lange et al. 2012). The endodontic absorbent paper point tear test (EAPPTT) was used in wild species, among them mammals, reptiles and birds (Lima et al. 2010, Lange et al. 2012, 2014, Huaringa et al. 2015, Oriá et al. 2015b, 2015c, Rajaei et al. 2015, 2016a, 2016b, MonçãoSilva et al. 2016a, 2016b, Araujo et al. 2017). This test is composed of a strip of absorbent material, with a small width, and the reading is performed by measuring the moist portion after 60 seconds (Lange et al. 2012).

The objective of this study was to evaluate and compare tear production in two species of juvenile opossums (D. albiventris e D. aurita) using PRTT, EAPPTT and mSTT.

\section{MATERIALS AND METHODS}

The study was approved by the Biodiversity Authorization and Information System (27489), the Ethics and Animal Welfare Committee of the Federal University of Bahia (73/2016) and conducted according to the precepts described by the Association for Research in Vision and Ophthalmology (ARVO).

Fifteen healthy juveniles white-eared opossums $(7$ males, 8 females) and fifteen Brazilian common opossums (8 males, 7 females), aged 60-90 days, from the Wild Animals Triage Center and the Getulio Vargas Zoobotanical Park (Salvador, Bahia, Brazil) were used in this research. Age was estimated based on phenotypic characteristics (D'Andrea et al. 1994, Shaw \& Renfree 2006). These animals were rescued after being found in peri-urban regions near the dead progenitor or in conditions requiring health care. Before this study, the animals were submitted to physical examination and palpebral reflexes, pupillary light reflexes, and menace responses of both eyes, by the local veterinary staff to exclude individuals with indications of systemic changes or gross abnormalities in the eye or periocular region. After collection, the selected animals were submitted to the fluorescein test (Ophthalmos ${ }^{\circledast}$, São Paulo, Brazil) to exclude specimens with corneal lesions. The data were collected with opossum physically restrained, and tests were performed with a 48-hour interval between 09:00 and 10:00 am. The ambient humidity and temperature were 60 to $63 \%$ and 28 to $29^{\circ} \mathrm{C}$, respectively.

The phenol red tear test (Zone-Quick ${ }^{\circledR}$, Oasis Medical, California, USA) was performed by inserting the cotton thread into the lower conjunctival sac of both eyes and maintained for 15 seconds (Fig.1A). Immediately after the removal, the reading was performed using a digital caliper (Mitutoyo ${ }^{\circledR}$, São Paulo, Brazil).
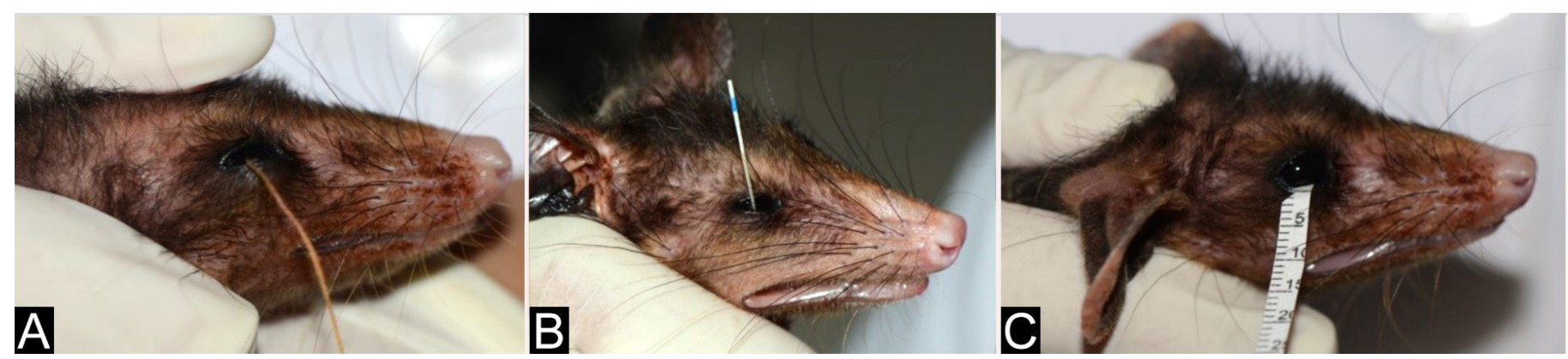

Fig.1. Quantitative measurement of tear production of Didelphis aurita. (A) Phenol red tear test, (B) endodontic absorbent paper point tear test, (C) modified Schirmer tear test. 
Table 1. Evaluation of tear production in juvenile white-eared opossum (Didelphis albiventris) and juvenile brazilian common opossum (Didelphis aurita) by three different methods

\begin{tabular}{ccccc}
\hline Specie & Parameter & Median $( \pm$ S-IQR $)$ & CI & P value \\
\hline White-eared opossum & PRTT & $19.79( \pm 2.61)^{\mathrm{a}}$ & $18.53-22.16$ & 0.95 \\
& EAPPTT & $16.25( \pm 1.82)^{\mathrm{b}}$ & $14.96-17.57$ & 0.54 \\
Brazilian common opossum & mSTT & $0.00( \pm 1.63)^{\mathrm{c}}$ & $0.00-3.00$ & $<0.01$ \\
& PRTT & $5.22( \pm 2.92)^{\mathrm{A}}$ & $3.91-8.06$ & 0.02 \\
& EAPPTT & $10.93( \pm 3.04)^{\mathrm{B}}$ & $7.95-11.87$ & 0.30 \\
& mSTT & $0.00( \pm 1.63)^{\mathrm{c}}$ & $0.00-3.00$ & $<0.01$
\end{tabular}

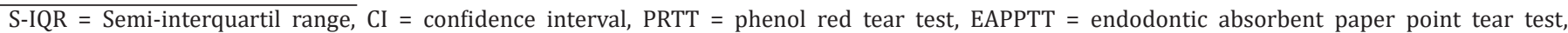
$\mathrm{mSTT}=$ modified Schirmer tear test; ${ }^{\mathrm{a}, \mathrm{b}, \mathrm{c}, \mathrm{A}, \mathrm{B}}$ Difference between uppercase and lowercase letters show statistical difference between the same test for the species studied $(\mathrm{P}<0.05)$; $\mathrm{P}$ value for the distribution of values for a given test in the same species.

The endodontic absorbent paper point tear test (Roeko color ${ }^{\circledR}$ - Color size 30, Langenau, Germany) was inserted into the lower conjunctival sac and maintained for 60 seconds (Fig.1B). Immediately after the removal, the reading was made using a digital caliper (Mitutoyo, São Paulo, Brazil).

The modified Schirmer tear test (Ophthalmos ${ }^{\circledR}$, São Paulo, Brazil) was performed with the strip cut in half using a No. 15 scalpel blade, to reduce its width from $5.0 \mathrm{~mm}$ to $2.5 \mathrm{~mm}$ (Conceição et al. 2011). The modified strip was inserted into the lower conjunctival sac and maintained for 60 seconds. After this period, the strip was removed and read immediately (Fig.1C).

Statistical analysis was performed with the $\mathrm{IBM}^{\circledR} \mathrm{SPSS}^{\circledR}$ software, version 20.0 , for the Windows ${ }^{\circledR}$ operating system (IBM Corporation, Somers, New York, USA). Quantitative data were assessed using the Shapiro-Wilk test. The Mann-Whitney and Wilcoxon tests were used for comparison between the PRTT, EAPPTT and mSTT, sex, and right and left eye. Spearman correlation was used to verify association between the variables. The level of significance was $5 \%$.

\section{RESULTS}

Difficulties were found to execute the tests due to the size and proximity of the vibrissae to the eye: when the strips leaned against the vibrissae, the animals reacted with palpebral incursion, which removed the test from the conjunctival sac. When compared, the execution of PRTT, despite having a shorter execution time, proved to be more difficult due to the excessive malleability of the wire. EAPPTT was easier to manipulate due to its relative stiffness, which made it easier to access the lower conjunctival sac. mSTT was considered intermediate compared to previous tests related to its use. Data for STT, PRTT and EAPPTT of both species, were not normally distributed by Shapiro-Wilk test $(P \geq 0,034)$. No significant differences were found in the comparison between the right and left eye and between sex ( $>>0.05)$. The medians of three evaluation methods are shown in Table 1. According to Mann-Whitney, there was a statistical difference when compared the same test between two species $(\mathrm{P}<0.05)$, except for mSTT. No significant correlations were found between tests for both species ( $\mathrm{P}>0.05)$.

\section{DISCUSSION}

Reports of tear production evaluation in opossum species were not found until now by the authors, although diseases in these animal's eyes were reported (Cáceres 2000). Once the establishment of tear production parameter is relevant for an adequate ophthalmic semiotechnique, such as the detection of differences between healthy and diseased eyes, this study presents 3 different methods, which provides information on values and adequacy of the methodology for the species, mainly in case of animals with a small eyelid cleft.

The choice of the most suitable test for a given species should be guided by the possibility of acquiring the results associated with minimum stress (Montiani-Ferreira et al. 2006). To obtain data on tear production, caution should be taken in the manipulation prior to the tests, since contact with the vibrissae during manipulation induces the flashing protective reflex. As reported in horses (Hendrix 2005, Grant et al. 2013), this can cause changes in the dynamics of the tear in the conjunctival sac (Tsubota \& Nakamori 1995).

PRTT-related performance difficulties were not reported in equines and cats, although these animals have abundance in vibrissae. Possibly, due to the size of the eyelid cleft (Sindak et al. 2010, Oriá et al. 2015a). When comparing different methods of tear production evaluation in an experimental model, EAPPTT is reported as a method that causes less discomfort to the ocular surface (Lima et al. 2010). In the present study, no differences were observed in the behavior of the animals in relation to the tests. However, features regarding execution have been reported, and it was pointed out that the use of EAPPTT allowed less contact with the vibrissae. For cats, Schirmer tear test caused greater discomfort (Oriá et al. 2015a), when compared the three tests. For opossums, mSTT has been considered easier than PRTT for being more rigid strip, but even the modified method was wider than the EAPPTT, causing more difficulties for execution.

There have already been reported different methods of tear production quantification, in rabbits (Lima et al. 2015), parrots (Monção-Silva et al. 2016a), macaws (Monção-Silva et al. 2016b) and green-iguanas (Araújo et al. 2017). In addition, the present study reports the use of different methods of measuring tear production in animals with small palpebral fissure length, such as marmoset and tortoise (Lange et al. 2012, Oriá et al. 2015b). Modifications on Schirmer tear test were suggested for neonatal dogs due to palpebral cleft size (Silva et al. 2013). However, studies of tear production in marsupials are scarce, with reports for koalas and kangaroos, using Schirmer tear test (Herring et al. 2000, Takle et al. 2010, Grundon et al. 2011). 
Similar results obtained for PRTT in white-eared opossums were described for swine, $16 \pm 4.7 \mathrm{~mm} / 15 \mathrm{~s}$ (Trost et al. 2007); owls (Megascops asio), $15 \pm 4.3 \mathrm{~mm} / 15 \mathrm{~s}$ (Harris et al. 2008); bats of the genus Pteropus, $20.23 \pm 1.28 \mathrm{~mm} / 15 \mathrm{~s}$ (Blackwood et al. 2010); chinchillas (Chinchilla lanigera), $14.6 \pm 3.5 \mathrm{~mm} / 15 \mathrm{~s}$ (Lima et al. 2010); marmoset (Callithrix penicillata), 13.27 \pm 5.41 (Lange et al. 2012); and parrots (Amazona amazonica), 21.9 $2.3 \mathrm{~mm} / 15 \mathrm{~s}$ (Monção-Silva et al. 2016a).

Despite the phylogenetic proximity, the Brazilian common opossum presented reduced values in comparison to the white-eared opossum. A value close to that obtained in this species was also observed in Syrian hamster (Mesocricetus auratus), 5.57 $\pm 1.51 \mathrm{~mm} / 15^{\prime \prime}$ (Rajaei et al. 2016a).

Prior study with EAPPTT for marmosets obtained values of $9.32 \pm 3.09 \mathrm{~mm} / \mathrm{min}$, similar to values for Brazilian common opossum (Lange et al. 2012). Assessments in animals with small eyelid cleft, as saffron finch (Sicalis flaveola) obtained $5.10 \pm 0.26 \mathrm{~mm} / \mathrm{min}$; chestnut-bellied seed-finch (Sporophila angolensis), $4.11 \pm 0.34 \mathrm{~mm} / \mathrm{min}$; mouse (Rattus norvegicus), $6.18 \pm 2.06 \mathrm{~mm} / \mathrm{min}$; mice (Mus musculus), $4.39 \pm 1.45 \mathrm{~mm} / \mathrm{min}$ (Lange et al. 2014), demonstrated values different to this study. Similar values to white-eared Opossum were obtained to parrots (Amazona amazonica), $14.9 \pm 1.65 \mathrm{~mm} / \mathrm{min}$ (Monção-Silva et al. 2016a); New Zealand rabbits, $13.8 \pm 1.5 \mathrm{~mm} / \mathrm{min}$ (Lima et al. 2015); english angora, $18.8 \pm 2.1 \mathrm{~mm} / \mathrm{min}$; and dutch rabbits, $16.9 \pm 1.7 \mathrm{~mm} / \mathrm{min}$ (Rajaei et al. 2016b).

Results of mSTT were similar to those obtained in marmosets (Lange et al. 2012), red-eared tortoise (Somma et al. 2015) and prairie dog (Meekins et al. 2015), ranging from 0 to $7 \mathrm{~mm}$, 0 to $5 \mathrm{~mm}$, and 0 to $4 \mathrm{~mm}$ respectively. Null or negative value in this type of quantitative test may suggest non-validation for these species, which highlights the need for adaptations of the methodology. Studies on marsupials with the unmodified Schirmer tear test, such as koalas (Phascolarctus cinereus), found values of $10.3 \pm 3.6 \mathrm{~mm} / \mathrm{min}$ and in red kangaroo (Macropus rufus), which is higher than those found in this study (Herring et al. 2000, Takle et al. 2010, Grundon et al. 2011).

Due to different characteristics of the three tests, extrapolate their values are not recommended, based in the non-correlation found between them. Studies of tear production in neonates and juveniles are reported for dogs (Silva et al. 2013), with a difference for adult individuals. From this, it is suggested to carry out further studies with evaluation of tear production in individuals of larger age groups. There was a notable difference in tear production between species, even with similar age and the same genus, which highlights the importance of knowledge regarding species-specific parameters.

The three tests show feasible options for the evaluation of tear production in white-eared opossum and Brazilian common opossum, and the implementation of EAPPTT was less difficult due to the stiffness of the strip that allowed less contact with the vibrissae. White-eared opossums have greater tear production than Brazilian common opossum for the evaluated tests, except for the modified Schirmer tear test.

\section{CONCLUSION}

The determination of these parameters for different tests of the tear film on white-eared opossum (Didelphis albiventris) and juvenile Brazilian common opossum (Didelphis aurita) represent important aid in the diagnosis of ocular diseases.
Acknowledgements.- The authors acknowledge Alberto Vinicius de Oliveira Dantas, Victor Pereira Curvelo and Ana Celly Lima Pinho from the Getúlio Vargas Zoobotanic Park and Fernanda de Azevedo Libório and Josiano Cordeiro Torezani from Triage Center for Wild Animals.

Conflict of interest statement. - The authors have no competing interests.

\section{REFERENCES}

Araujo N.L.L.C., Raposo A.C.S., Muramoto C., Meneses I.D.S., Bittencourt M.V., Martins Filho E.F. \& Oriá A.P. 2017. Evaluation of selected ophthalmic diagnostic tests in green iguanas (Iguana iguana). J. Exot. Pet Med. 26(3):176187. <http://dx.doi.org/10.1053/j.jepm.2017.05.009>

Astua de Moraes D., De la Sancha N. \& Costa L. 2015. Didelphis aurita, Brazilian Common Opossum. The IUCN Red List of Threatened Species. Available at <<http://dx.doi.org/10.2305/IUCN.UK.2015-4.RLTS.T40500A22175929.en>

Beech J., Zappala R.A., Smith G. \& Lindborg S. 2003. Schirmer tear test results in normal horses and ponies: effect at age, season, environment, sex, time of day and placement of strips. Vet. Ophthalmol. 6(3):251-254. <http:// dx.doi.org/10.1046/j.1463-5224.2003.00302.x><PMid:12950657>

Blackwood S.E., Plummer C.E., Crumley W., Mackay E.O., Brooks D.E. \& Barrie K.P. 2010. Ocular parameters in a captive colony of fruit bats. Vet. Ophthalmol. 13(Suppl.):72-79. <http://dx.doi.org/10.1111/j.1463-5224.2010.00816. $\mathrm{x}><$ PMid:20840093>

Cáceres N.C. 2000. Population ecology and reproduction of the White-eared opossum Didelphis albiventris (Mammalia, Marsupialia) in an urban environment of Brazil. J. Braz. Assoc. Adv. Sci. 52(3):171-174.

Cáceres N.C. \& Monteiro-Filho E.L.A. 1998. Population dynamics of the common opossum, Didelphis marsupialis (Mammalia, Marsupialia), in southern Brazil. Z. Säugetierk. 63:169-172.

Conceição L.F., Ribeiro A.P., Torres M.L.M., Lourenço M.L.G. \& Laus J.L. 2011. Evaluation of tear production with modified Schirmer tear test-1 during the neonatal period in cats. Pesq. Vet. Bras. 31(4):350-354. <http://dx.doi. org/10.1590/S0100-736X2011000400013>

Costa L.P., Astua de Moraes D., Brito D., Soriano P. \& Lew D. 2015. Didelphis albiventris, White-eared Opossum. The IUCN Red List of Threatened Species. Available at <http://dx.doi.org/10.2305/IUCN.UK.2015-4.RLTS. T40489A22176404.en>

D’Andrea P.S., Cerqueira R. \& Hingst E.D. 1994. Age estimation of the Gray Four Eyed Opossum, Philander opossum (Didelphimorphia: Didelphidae). Mammalia 58(2):283-291.

Ghaffari M.S., Hajikhani R., Sahebjam F., Akbarein H. \& Golezardy H. 2012. Intraocular pressure and Schirmer tear test result in clinically normal LongEared Hedgehogs (Hemiechimus auritus): reference values. Vet. Ophthalmol. 15(3):206-209. <http://dx.doi.org/10.1111/j.1463-5224.2011.00967.x> $<$ PMid:22050958>

Grant R.A., Haidarliu S., Kennerley N.J. \& Prescott T.J. 2013. The evolution of active vibrissal sensing in mammals: evidence from vibrissal musculature and function in the marsupial opossum Monodelphis domestica. J. Exp. Biol. 216(Pt 18):3483-3494. <http://dx.doi.org/10.1242/jeb.087452> <PMid:23737559>

Grundon R.A., Anderson G.A., Lynch M., Hardman C., O’Reilly A. \& Stanley R.G. 2011. Schirmer tear test and intraocular pressures in conscious and anesthetized koalas (Phascolarectus cinereus). Vet. Ophthalmol. 14(5):292-295. <http://dx.doi.org/10.1111/j.1463-5224.2010.00872. x $><$ PMid:21929605>

Harris M.C., Schorling J.J., Herring I.P., Elvinger F., Bright P.R. \& Pickett I.P. 2008. Ophtalmic examination findings in a colony of screech owl (Megascops asio). Vet. Ophthalmol. 11(3):186-192. <http://dx.doi. org/10.1111/j.1463-5224.2008.00618.x><PMid:18435661>

Hendrix D.V.H. 2005. Eye examination techniques in horses. Clin. Tech. Equine Pract. 4(1):2-10. <http://dx.doi.org/10.1053/j.ctep.2005.03.010> 
Herring I.P., Pickett J.P., Champagne E.S. \& Marini M. 2000. Evaluation of aqueous tear production in dogs following general anesthesia. J. Am. Anim. Hosp. Assoc. 36(5):427-430. <http://dx.doi.org/10.5326/15473317-365-427><PMid:10997519>

Hida R.Y., Nishiwaki-Dantas M.C., Hida M.M. \& Tsubota K. 2005. Quantitative tear study using the red phenol test in the Brazilian population. Arq. Bras. Oftalmol. 68(4):433-437. <http://dx.doi.org/10.1590/S000427492005000400004><PMid:16322825>

Holt E., Rosenthal K. \& Shofer F.S. 2006. The phenol red thread tear test in large Psittaciformes. Vet. Ophthalmol. 9(2):109-113. <http://dx.doi. org/10.1111/j.1463-5224.2006.00450.x><PMid:16497235>

Huaringa P.V., Grandez R.R. \& Hinostroza M.E. 2015. Comparación entre la prueba de puntas de papel absorbente estériles y la prueba lagrimal de Schirmer para la evaluación de producción de lágrimas en canes clínicamente normales. Revta Invest. Vet. Perú 26(3):412-419.

Lange R.R., Lima L. \& Montiani-Ferreira F. 2012. Measurement of tear production in black-tufted marmosets (Callithrix penicillata) using three different methods: modified Schirmer's I. phenol red thread and standardized endodontic absorbent paper points. Vet. Ophthalmol. 15(6):376-382. <http://dx.doi.org/10.1111/j.1463-5224.2012.00998.x><PMid:22348283>

Lange R.R., Lima L., Przydzimirski A.C. \& Montiani-Ferreira F. 2014. Reference values for the production of the aqueous fraction of the tear film measured by the standardized endodontic absorbent paper point test in different exotic and laboratory animal species. Vet. Ophthalmol. 17(1):41-45. <http:// dx.doi.org/10.1111/vop.12038> <PMid:23464753>

Lima L., Lange R.R., Turner-Giannico A. \& Montiani-Ferreira F. 2015. Evaluation of standardized endodontic paper point tear test in New Zealand white rabbits and comparison between corneal sensitivity followed tear tests. Vet. Ophthalmol. 18(Suppl.1):119-124. <http://dx.doi.org/10.1111/ vop.12178><PMid:24799158>

Lima L., Montiani-Ferreira F., Tramontin M., Leigue Dos Santos L., Machado M., Ribas Lange R. \& Helena Abil Russ H. 2010. The chinchila eye: morphologic observations. echobiometric findings and reference values for selected ophthalmic diagnostic test. Vet. Ophthalmol. 13(Suppl.):14-25. <http:// dx.doi.org/10.1111/j.1463-5224.2010.00785.x> <PMid:20840086>

McMenamin P.G. \& Krause W.J. 1993. Development of the eye in the North American opossum (Didelphis virginiana). J. Anat. 183(Pt 2):343-358. <PMid:8300421>

Meekins J.M., Eshar D. \& Rankin A.J. 2015. Tear production, intraocular pressure, and conjunctival bacterial flora in a group of captive black-tailed prairie dogs (Cynomys ludovicianus). Vet. Ophthalmol. 18(Suppl.1):132-136. <http://dx.doi.org/10.1111/vop.12226><PMid:25319723>

Monção-Silva R., Ofri R., Raposo A.C., Araújo N., Torezani J., Muramoto C. \& Oriá A. 2016a. Ophthalmic diagnostic tests in parrots (Amazona amazonica) and (Amazona aestiva). J. Exot. Pet. Med. 25(3):186-193. <http://dx.doi. org/10.1053/j.jepm.2016.05.002>

Monção-Silva R., Ofri R., Raposo A.C.S., Libório F.A., Estrela-Lima A. \& Oriá A.P. 2016b. Ophthalmic parameters of Blue-and-yellow Macaws (Ara ararauna) and Lear's Macaws (Anodorhynchus leari). Avian Biol. Res. 9(4):1-10.<http://dx.doi.org/10.3184/175815516X14725499175746>

Montiani-Ferreira F., Mattos B.C. \& Russ H.H.A. 2006. Reference values for selected ophthalmic diagnostic test of the ferret (Mustela putorius furo). Vet. Ophthalmol. 9(4):209-213.<http://dx.doi.org/10.1111/j.1463-5224.2006.00475. $\mathrm{x}><$ PMid:16771755>
Oriá A.P., Martins Filho E.F., Raposo A.C.S., Araújo N.L.L.C. \& Gomes Junior D.C. 2015a. Lacrimal production of cats: Schirmer tear test, Phenol red thread tear test and endodontic absorbent paper point. Enc. Bios. 11(2):2085-2091.

Oriá A.P., Silva R.M., Pinna M.H., Oliveira A.V., Ferreira P.R., Martins Filho E.F., Meneses I.D., Requião K.G. \& Ofri R. 2015b. Ophthalmic diagnostic tests in captive red-footed tortoises (Chelonoidis carbonaria) in Salvador, northeast Brazil. Vet. Ophthalmol. 18(Suppl.1):46-52.<http://dx.doi.org/10.1111/ vop.12175><PMid:24783966>

Oriá A.P., Oliveira A.V., Pinna M.H., Martins Filho E.F., Estrela-Lima A., Peixoto T.C., Silva R.M., Santana F.O., Meneses Í.D., Requião K.G. \& Ofri R., Requião K.G. \& Ofri R. 2015c. Ophthalmic diagnostic tests, orbital anatomy, and adnexal histology of the broad-snouted caiman (Caiman latirostris). Vet. Ophthalmol. 18(Suppl.1):30-39. <http://dx.doi.org/10.1111/vop.12115> <PMid:24171896>

Rajaei S.M., Ansari Mood M., Khorram H., Selk Ghaffari M. \& Williams D.L. 2015. Measurement of tear production using the phenol red thread test in the common mynah (Acridotheres tristis). J. Avian Med. Surg. 29(2):146148. <http://dx.doi.org/10.1647/2013-079><PMid:26115216>

Rajaei S.M., Mood M.A., Sadjadi R. \& Williams D.L. 2016a. Results of selected ophthalmic diagnostic tests for clinically normal Syrian hamsters (Mesocricetus auratus). Am. J. Vet. Res. 77(1):72-76. <http://dx.doi. org/10.2460/ajvr.77.1.72> <PMid:26709939>

Rajaei S.M., Rafiee S.M., Ghaffari M.S., Masouleh M. \& Jamshidian M. 2016b. Measurement of tear production in english angora and dutch rabbits. J. Am. Assoc. Lab. Anim. Sci. 55(2):221-223. <PMid:27025815>

Shaw G. \& Renfree M.B. 2006. Parturition and perfect prematurity: birth in marsupials. Aust. J. Zool. 54(3):139-149. <http://dx.doi.org/10.1071/ Z005070>

Silva E.G., Sandmeyer L.S., Gionfriddo J.R., Montiani-Ferreira F. \& Galera P.D. 2013. Tear production in canine neonates, evaluation using a modified Schirmer tear test. Vet. Ophthalmol. 16(3):175-179. <http://dx.doi. org/10.1111/j.1463-5224.2012.01044.x><PMid:22812914>

Sindak N., Kandemir L., Yertürk M. \& Biricik H.S. 2010. Measurement of phenol red thread tear test in Arabian and throughbred horses. Vet. Ophthalmol. 13(4):219-221. <http://dx.doi.org/10.1111/j.1463-5224.2010.00786. $\mathrm{x}><$ PMid:20618798>

Somma A.T., Lima L., Lange R.R., Turner-Giannico A. \& Montiani-Ferreira F. 2015. The eye of the red-eared slider turtle: morphologic observations and reference values for selected ophthalmic diagnostic tests. Vet. Ophthalmol. 18(Suppl.1):61-70.<http://dx.doi.org/10.1111/vop.12213> $<$ PMid:25209440>

Takle G.L., Suedmeyer W.K. \& Hunkeler A. 2010. Selected diagnostic ophthalmic test in the red kangaroo (Macropus rufus). J. Zoo Wildl. Med. 41(2):224233. <http://dx.doi.org/10.1638/2009-0105R1.1><PMid:20597213>

Trbolova A. \& Ghaffari M.S. 2012. Reference values for Schirmer tear test I and II in clinically normal pigs. Vet. Ophthalmol. 15(3):180-182. <http:// dx.doi.org/10.1111/j.1463-5224.2011.00960.x><PMid:22050769>

Trost K., Skalicky M. \& Nell B. 2007. Schirmer tear test, Phenol red thread tear test, eye blink frequency and corneal sensitivity in the guinea pig. Vet. Ophthalmol. 10(3):143-146. <http://dx.doi.org/10.1111/j.1463-5224.2007.00521.x> $<$ PMid:17445074>

Tsubota K. \& Nakamori K. 1995. Effects of ocular surface area and blink rate on tear dynamics. Arch. Ophthalmol. 113(2):155-158. <http://dx.doi. org/10.1001/archopht.1995.01100020037025><PMid:7864746> 